\title{
Biochemical effects of potato irradiation on potato tuber moth, Phthorimaea operculella Zeller (Lepidoptera - Gelechiidae)
}

\author{
Iman M. Haiba ${ }^{1}$ and Mona F. Abd-El Aziz ${ }^{2}$ \\ 1-National Center for Radiation Research and Technology \\ 2- Benha Univ. Faculty of Science, Entomol. Department
}

\section{ABSTRACT}

Effect of gamma radiation on the whole body contents of nutritional materials was investigated for potato tuber moth, Phthorimaea operculella Zeller, fed on irradiated potato tubers. The statistical analysis of the data indicated that the quantities of carbohydrates, proteins and lipids in the whole body of the adults of $P h$. operculella were affected significantly. There was a correlation with their changes in the potato tubers; as a significant decrease in protein and carbohydrate contents was recorded for potato tubers and both male and female moths at most doses. Although lipid was recorded as a trace amount in both non-irradiated and irradiated potatoes it was significantly increased in males fed on irradiated potatoes at all doses. While a significant decrease in lipid contents at lower doses (50 and 70 Gy) was recoded, a significant increase at higher doses $(100,150$ and $200 \mathrm{~Gy})$ was noticed in case of females. The total body weight of insects was affected directly with the increase in the dose of potato irradiation

Key words: Phthorimaea operculella, potato tubers, gamma radiation, biochemical component, protein, lipid and carbohydrate.

\section{INTRODUCTION}

The potato tuber moth, Phthorimaea operculella Zeller (PTM) is one of the most destructive pests of cultivated potato worldwide either in the field or storage. The larvae mine into the leaves and stems of young plants, and bore into the tubers as soon as they are formed. During storage, the damaged tubers rot and become unsuitable for human consumption. The adult moth flies from the infested tubers in the storage and from neglected small lots in warehouses or farms to the fields where it causes pre-harvest infestation. Conventional control methods are not very successful because the larvae pass a major portion of their life inside the tubers (Haiba, 1990).

One third of the world's food supply is lost post-harvest as a result of too rapid ripening, sprouting in storage, insect infestation, and bacterial and fungal attack. Chemical insecticides that are widely applied for disinfestations cause health hazards to human beings and environment. To alleviate these problems, ionizing radiation, e.g. gamma rays, X-rays or electrons, can be used to extend the life of certain fruits and vegetables by delaying ripening or killing moulds, and for the control of insect infestation of grains and other stored products. It is also a safer and cheaper control method \{ Elvin, et al., (1974); Khan, (1990); Henry, (1998); Guy, (1999); Farkas, (2006); Villavicencio et al., (2007) and Bhat and. Sridhar, (2008)\}.

Generally, it is well known that the growth of phytophagous larvae is indirectly influenced by the chemical or physical factors, or both, which characterized their host plants. In term of chemical factors, the plant may be low in some essential nutrient, or have growth inhibiting compounds, or both (Reese and Field 1986 ). 
The biological disturbance in PTM due to their rearing on irradiated potato tubers with gamma rays was investigated by Rananavare et al., (1991); Haiba, (1994 and 2000) and Saour et al., (1999). Haiba, (1994 and 2000) found that the irradiation of potato tubers with 50, 70, 100, 150 and 200 Gy affected significantly most biological aspects of PTM. As significant reduction in fertility, fecundity and percentage of pupation and adult emergence were recorded. Also the emerged adults exhibited some malformations especially in the higher doses.

The present study measures the quantity of carbohydrates, proteins and lipids in the whole body of Ph. operculella, in both sexes fed on non-irradiated potato tubers. The aim of this study is to compare both results to explain if there is an adequate relationship between the biochemical content of the insects and potato irradiation and also to explain the reasons of the disturbance in biology due to their feeding on irradiated potatoes previously reported by Haiba, (1994 and 2000).

\section{MATERIALS AND METHODS}

The potato tuber moths, Ph. operculella, were reared in the laboratory of Entomology Deparment, in Benha University, Faculty of Sciences according to Haiba, (1990).

Experiments were carried out on the whole body of unmated newly emerged moths, resulting from larvae fed on irradiated potato tubers (Spunta variety) with doses $0,50,70,100,150$ and 200 Gy according to Haiba, (1994 and 2000) under laboratory conditions of temperature $30 \pm 2{ }^{\circ} \mathrm{C}$.

Potato Irradiation was carried out through the model 3500 Gamma Cell Irradiation Unit $\left({ }^{60} \mathrm{Co}\right.$ source) installed in the Middle Eastern Regional Radioisotope Center for the Arab Countries with a dose rate $1.3 \mathrm{rad} / \mathrm{Sec}$.

Analysis of proteins, carbohydrates, and lipids was carried out by methods described by Bradford. (1976); Singh, (1977) and Knight et al., (1972), respectively in the Plant Protection Research Institute.

Effect of potato irradiation on the body weight of both newly emerged male and female moths was recorded (14 insect/three replicates).

The results obtained were statistically analyzed by using Duncan's Multiple range (Gomez and Gomez 1984).

\section{RESULTS}

Effects of different gamma radiation doses on the biochemical components of potato tubers and both female and male moths of Ph. operculella that emerged from larvae fed on non-irradiated and irradiated potatoes, are given in Tables 1,2 and 3, respectively. The effect of potato irradiation on the body weight of both male and female moths was recorded in Table (4). 
Table (1): Effect of gamma radiation on nutritional materials of potato tubers.

\begin{tabular}{|c|c|c|}
\hline \multirow{2}{*}{ Dose in Gy* } & \multicolumn{2}{|c|}{$\begin{array}{c}\text { Nutritional Materials } \\
\text { (mg/g. tuber) }\end{array}$} \\
\hline & Carbohydrates & Proteins \\
\hline $\mathbf{0}$ & $3767 \pm 42^{\mathfrak{c}}$ & $1619 \pm 19^{c}$ \\
\hline 50 & $3054 \pm 48^{\mathrm{e}}$ & $950 \pm 18^{f}$ \\
\hline 70 & $2975 \pm 28^{\mathrm{e}}$ & $1022 \pm 23^{\mathrm{e}}$ \\
\hline 100 & $4256 \pm 21^{\mathrm{a}}$ & $1485 \pm 17^{d}$ \\
\hline 150 & $4137 \pm 35^{b}$ & $1733 \pm 20^{\mathbf{b}}$ \\
\hline 200 & $3423 \pm 32^{d}$ & $1862 \pm 30^{a}$ \\
\hline
\end{tabular}

Means, within a column, bearing different subscripts are significantly different $(\mathrm{P}<0.01)$

*Trace amounts of lipids were found which were difficult to detect.

Table (2): Effect of gamma radiation on nutritional materials of newly emerged females of $P h$. operculella from larvae fed on irradiated potato tubers reared under laboratory conditions of temperature $30 \pm 2{ }^{\circ} \mathrm{C}$.

\begin{tabular}{|c|c|c|c|}
\hline \multirow{2}{*}{ Dose In Gy } & \multicolumn{3}{|c|}{$\begin{array}{c}\text { Nutritional Materials } \\
\text { (mg/g. b.wt) }\end{array}$} \\
\hline & Carbohydrate & Protein & Lipid \\
\hline $\mathbf{0}$ & $34.8 \pm 0.75^{\mathbf{b}}$ & $41.36 \pm 0.7^{\mathrm{a}}$ & $21.56 \pm 0.3^{\mathbf{b}}$ \\
\hline 50 & $28.4 \pm 0.32^{d}$ & $32.63 \pm 1.6^{\mathbf{b}}$ & $18.3 \pm 0.32^{\mathrm{c}}$ \\
\hline 70 & $31.4 \pm 0.37^{\mathfrak{c}}$ & $23.4 \pm 0.83^{\mathrm{d}}$ & $16 \pm 0.17^{\mathrm{d}}$ \\
\hline 100 & $36 \pm 0.6^{\mathrm{a}}$ & 18. $5 \pm 0.17^{\mathrm{e}}$ & $17.7 \pm 0.31^{\mathrm{cc}}$ \\
\hline 150 & $27.9 \pm 0.34^{\mathrm{d}}$ & $28.9 \pm 0.17^{\mathfrak{c}}$ & $34.2 \pm 0.77^{\mathrm{a}}$ \\
\hline 200 & $28.6 \pm 0.4^{\mathrm{d}}$ & $18.7 \pm 1.22^{\mathrm{e}}$ & $35.8 \pm 1.66^{\mathrm{a}}$ \\
\hline
\end{tabular}

Means, within a column, bearing different subscripts are significantly different $(\mathrm{P}<0.01)$ 
Table (3): Effect of gamma radiation on nutritional materials of newly emerged males of $P h$. operculella from larvae fed on irradiated potato tubers reared under laboratory conditions of temperature $3 \mathrm{o} \pm 2{ }^{\circ} \mathrm{C}$.

\begin{tabular}{|c|c|c|c|}
\hline \multirow{2}{*}{ Dose In Gy } & \multicolumn{3}{|c|}{$\begin{array}{c}\text { Nutritional Materials } \\
\text { (mg/g. b.wt) }\end{array}$} \\
\hline & Carbohydrate & Protein & Lipid \\
\hline $\mathbf{0}$ & $46 \pm 0.6^{\mathrm{a}}$ & $37.8 \pm 1.05^{\mathbf{b}}$ & $17.8 \pm 0.84^{\mathbf{c}}$ \\
\hline 50 & $32.6 \pm 1.5^{\mathrm{d}}$ & $23.66 \pm 1.2^{\mathrm{d}}$ & $21.8 \pm 0.43^{\mathbf{b}}$ \\
\hline 70 & $34.9 \pm 1.8^{\mathrm{cd}}$ & $32.98 \pm 0.5^{\mathrm{c}}$ & $26.3 \pm 0.49^{\mathrm{a}}$ \\
\hline 100 & $36.4 \pm 0.5^{\mathrm{bc}}$ & $19.3 \pm 0.6^{\mathrm{e}}$ & $20.9 \pm 0.95^{\mathbf{b}}$ \\
\hline 150 & $39.3 \pm 1.04^{\mathbf{b}}$ & $33.5 \pm 0.47^{\mathrm{c}}$ & $22.4 \pm 1.21^{\mathrm{b}}$ \\
\hline 200 & $47.6 \pm 1.05^{\mathrm{a}}$ & $52.5 \pm 1.4^{\mathrm{a}}$ & $26 \pm 0.86^{\mathbf{a}}$ \\
\hline
\end{tabular}

Means, within a column, bearing different subscripts are significantly different $(\mathrm{P}<0.01)$

The amounts of carbohydrates and proteins in potato tubers (Table1) were statistically affected by gamma radiation. The carbohydrate contents were significantly decreased at all doses except at 100 and 150 Gy $(4256$ and $4137 \mathrm{mg} / \mathrm{g}$. tuber, respectively); it was significantly increased than the control $(3767 \mathrm{mg} / \mathrm{g}$. tuber).

A significant reduction in protein content was recorded at lower doses comparing with the non-irradiated potatoes. However, a significant increase was measured at the higher doses 150 and $200 \mathrm{~Gy}(1733$ and $1862 \mathrm{mg} / \mathrm{g}$. tuber, respectively). Trace amounts of lipids was recorded in both control and irradiated potatoes but it was difficult to detect.

The whole body contents of proteins, carbohydrates and lipids for both females and males reared as larvae on irradiated potato tubers were significantly affected compared with those reared on non-irradiated ( Tables 2and 3, respectively).

Carbohydrate content was decreased significantly in case of males and females at all doses compared with the control, while it was significantly increased at the dose $100 \mathrm{~Gy}(\mathrm{P}<0.01)$ for females $(36 \pm 0.6 \mathrm{mg} / \mathrm{g} . \mathrm{b} . \mathrm{wt})$ and no significant change was measured at the dose 200 Gy for males.

The total protein content was decreased significantly in both males and females at all doses than the control, except in case of the dose 200 Gy a significant increase $(\mathrm{P}<0.01)$ in male protein contents was measured (52.5 mg/g.b.wt).

Although lipid content was recorded as a trace amount in both nonirradiated and irradiated potatoes it was significantly increased in males fed on irradiated potatoes at all doses. However, the data of females indicated a significant decrease in lipid contents at lower doses (50,70 and $100 \mathrm{~Gy})$ and a significant increase at higher doses $(150$ and $200 \mathrm{~Gy})(\mathrm{P}<0.01)$. 
Table (4): Effect of gamma radiation on body weight of newly emerged females and males of $P h$. operculella from larvae fed on irradiated potato tubers reared under laboratory conditions of temperature $3 \mathrm{o} \pm 2{ }^{\circ} \mathrm{C}$.

\begin{tabular}{|c||c|c|}
\hline \multirow{2}{*}{ Dose in Gy* } & Female & Made \\
\hline \hline $\mathbf{0}$ & $71.93 \pm 0.83^{\mathbf{e}}$ & $48.17 \pm 0.76^{\mathbf{c}}$ \\
\hline $\mathbf{5 0}$ & $82.97 \pm 0.85^{\mathbf{c}}$ & $61.57 \pm 1.50^{\mathbf{b}}$ \\
\hline $\mathbf{7 0}$ & $84.13 \pm 0.98^{\mathbf{c}}$ & $67.23 \pm 0.68^{\mathbf{a}}$ \\
\hline $\mathbf{1 0 0}$ & $77.8 \pm 1.31^{\mathbf{d}}$ & $64.17 \pm 0.76^{\mathbf{a}}$ \\
\hline $\mathbf{1 5 0}$ & $95.13 \pm 2.80^{\mathbf{a}}$ & $61.5 \pm 0.5^{\mathbf{b}}$ \\
\hline $\mathbf{2 0 0}$ & $89.96 \pm 0.95^{\mathbf{b}}$ & $59.1 \pm 1.05^{\mathbf{b}}$ \\
\hline
\end{tabular}

Means, within a column, bearing different subscripts are significantly different $(\mathrm{P}<0.01)$

*14 insects for each replicate (three replicates).

The total body weight of both females and males (Table 4) increased in insects fed on irradiated potatoes than those fed on non-irradiated potatoes. The heaviest female and male weights (95.13 and $67.23 \mathrm{mg} / 14$ insects, respectively) were obtained when female and male larvae were fed on 150 and 70 Gy irradiated potatoes, respectively and the lightest weights for both females and males were recorded at the control (71.93 and $48.17 \mathrm{mg} / 14$ insects, respectively).

\section{DISCUSSION}

Gamma irradiation of potato tubers showed significant biochemical changes in tubers and their pest potato tuber moth, Ph. operculella, which was fed at the larval stage on irradiated tubers.

The total carbohydrate contents of potato tubers irradiated with doses 50,70 and $200 \mathrm{~Gy}$ were lower than the control, whereas they were higher for doses 100 and 150 Gy. A significant reduction in tuber protein contents were measured at lower doses comparing with the control. However a significant increase was measured at the higher doses 150 and 200 Gy. Elton, (1978) reported that the potato tubers provide a significant amount of protein, carbohydrate, vitamin $\mathrm{C}$ and iron. He reported that carbohydrates were the main energy source.

The present study showed that trace amounts of lipids were found in potato tubers and it was difficult to detect. Mondy and Mueller, (1977) demonstrated that all the root crops and tubers exhibit a very low lipid content. These are mainly structural lipid of the cell membrane which enhance cellular integrity, offer resistance to bruising and help to reduce enzymic browning Similar results were observed by many authors, as Jaarma, (1958) who stated that in tubers irradiated with 40-100 Gy, sucrose and glucose increased while fructose decreased. While Filep and 
Koposztassy, (1971) observed a reduction in sucrose content following irradiation. Kai Fu et al.,(1977) reported that irradiation of tubers with various doses induced reduction total sugars, lipids, proteins and fiber. Becker and Somogyi, (1977) observed an increase in sucrose contents with the increase of dose level.

Other authors showed no significant impairment in the nutritional quality of proteins, lipids and carbohydrates constituents when foods were exposed to ionizing radiation \{(Godwin,; Josephson el al., (1979); Kashani and Valadon, (1984) and Kovács et al., (1986)\}.

In an attempt to understand some of the changes induced in potato tubers by irradiation many researchers have investigated the effect of irradiation on carbohydrate metabolizing enzymes. Ussuf and Nair, (1972) showed that phosphorylase activating was increased within 2 hours of irradiation $(10 \mathrm{Krad})$, but doses as high as $500 \mathrm{Krad}$ decreased activity. Becker and Somogyi, (1977) demonstrated that the increase of sucrose after irradiation was related to a rise in phosphorylase activity ranging from $147-355 \%$, depending on variety. Increases in phosphor-glucomutase, UDP-glucose-pyrophosphorylase, sucrose synthase and sucrose phosphate synthase have also been reported by (Hayashi and Aoki, 1985).

One of the main effects of ionizing radiation on carbohydrates in food is the abstraction of hydrogen from the carbon-hydrogen bonds of the carbohydrate, resulting in directly ionizing and exciting the carbohydrate molecule. Carbohydrate radicals may result from ionization of monosaccharides such as glucose or polysaccharides such as starch. Starch may be degraded into dextrins, maltose, and glucose. Sugar acids, ketones, and other sugar monosaccharides may also be formed as a result of ionizing radiation. (Diehl, 1995).

With respect to proteins, several types of reactions can occur as a result of irradiation. One type of reaction is the breaking of a small number of peptide bonds to form polypeptides of shorter length than the original protein. Radiation induced aggregation or cross-linking of individual polypeptide chains can also occur; these processes result in protein denaturation (Urbain, 1977).

The present study revealed that the quantities of carbohydrates, proteins and lipids in the whole body of Ph. operculella were affected significantly in both males and females when fed on irradiated potato tubers as larvae comparing with the control. A significant decrease in carbohydrate contents was recorded for both males and females at 50, 70 and 200 Gy doses. Whereas a significant increase was recorded at the dose 100 Gy for females and no significant change was measured at the dose 200 Gy for males.

A distinct quantitative decrease in carbohydrate composition in insects fed on gamma irradiated mung beans was observed by Machaia et al., (1999) due to the reducing sugar, mainly glucose, fructose and glactose. The same results observed by Machaiah and Pednkar, (2002) when insects fed on gamma irradiated legumes.

Carbohydrate serve as a source of energy and may be converted to fats for storage and to amino acids (Chapman, 1998). Carbohydrate are the most important nutrients affecting reproduction and longevity ( Stephanie and Fischer, 2005).

In the present study, the total protein contents were lower significantly in both males and females at all doses than the control, except in case of the dose 200Gy where a significant increase in male protein contents was measured.

Protein has been shown to affect important individual-level fitness-associated traits such as body size, growth rate, and fecundity; and at higher levels of organization has been linked to population dynamics, life histories, and even biological diversification \{(Joern and Behmer, 1997) and (Fagan et al., 2002)\}. 
Protein is important for yolk production and the diet of the female insect may be modified to provide this protein. During the early stages of egg development much protein is ingested and the intake of protein stimulates the corpora allata which secrete a factor leading to increased carbohydrate intake during the period of yolk deposition in the eggs (Engelmann,1969).

Amino acids, usually present as protein, are required for the production of tissues and enzymes. The absence of any one of the amino acids usually prevent growth (Chapman, 1998).

The present data showed that although lipid was recorded as a trace amount in both non-irradiated and irradiated potatoes it was significantly increased in males and females fed on irradiated tubers at all doses than those of control. Except for females fed on irradiated potato tubers with lower doses 5070 and 100 Gy a significant decrease in lipid contents was measured.

Lipids are found in both plants and animals, where they operate as electron carriers, substrate carriers in enzymatic reactions, components of biological membranes, and sources and stores of energy. Sterols, fatty acids, fat-soluble vitamins, and carotenoids are examples of lipids that are either essential or considered important for plant-feeding insects. Sterols serve as structural components in cellular membranes and as precursors for steroid hormones (e.g., molting hormone). Most plant-feeding insects also have a dietary requirement for polyunsaturated fatty acids. Generally plant-feeding insects grow well when linoleic or linolenic acid is present in the diet (Dadd, 1985). The effect of omitting fatty acids from the diet varies from species to species. For example, in the Lepidoptera and Hymenoptera, adults fail to develop properly if linolenic acid is omitted from their larval diet (Chapman, 1998).

Growth during the last larval stadium is entirely somatic and characterized by a great accumulation of a lipid rich fat body. With poor dietary lipid both larvae and adults had to synthesize additional lipid from carbohydrate to supplement absorbed lipids for growth demands. Almost all absorbed and synthesized lipids were used for somatic growth in the larvae and for ovarial growth in the adults. Some carbohydrate was used for lipid synthesis but very little was used for growth (Woodring et al., 1979). Compensatory feeding among low-protein larval diet is correlated with significantly higher fat content in larvae, pupae and adults, whereas low-sucrose animals were substantially leaner than those on the control diet. These differences may have strong effects on adult physiology, reproduction, and foraging patterns (Avila, et al., 2003).

Our data showed that through out all dietary treatment, the total body weight of both males and females was positively correlated to potato irradiation doses. and the lightest weights for both males and females were recorded at the control. This could be related to the higher lipid contents which are synthesized from carbohydrate. Smith et al., (2006) stated that the consumption of energy-rich diets can lead to obesity and is associated with deleterious consequences. The authors reared Plutella xylostella caterpillars for multiple generations on carbohydrate-rich foods and they noticed the restriction to a high-carbohydrate diet over multiple generations in Plutella leads to lowered deposition of body fat for the same consumption of carbohydrate, whereas restriction to a low-carbohydrate diet leads to enhanced fat storage. These results strongly imply that excess fat storage has a fitness cost and that such a cost is worth paying in environments where carbohydrate is scarce.

Generally, it is well known that chemical compounds and alkaloids or other secondary plant metabolites can be considered as feeding or oviposition inhibiting agent for many insect specie (Vigneron,1978). It is generally believed that 
Lepidoptera, as is the case in many holometabolous insects, rely primarily on nutrients accumulated during the larval stage for somatic maintenance and reproductive output $\{$ (Telang et al., 2001) and (Stephanei and Fischer, 2005)\}.

The results of the present work may discuss the reasons of disturbance in the percentage of emergency, fecundity, fertility and malformations of Ph operculella, fed as larvae on irradiated potato tubers with the doses 50, 70, 100, 150 and $200 \mathrm{~Gy}$ which previously observed by Haiba, (1994 and 2000) because the diet plays an important role in egg production by female insects. Dietary deficiencies may result in a disturbance of yolk synthesis. Storage protein have been found to play a major role in insect metamorphosis and egg production and are accumulated during the actively feeding larval stage (Telang et al., 2002). The importance of larval nourishment for mosquito, Ochlerotatus atropalpus, was studied by Telang and wells, (2004) they showed that larval nourishment strongly influenced autogenous eggproduction: female larvae that were nutritionally stressed emerged as smaller adults, produced fewer eggs and emerged with less protein, lipid and glycogen stores.

In conclusion, the potato tuber irradiation affected significantly the whole body contents of nutritional materials, carbohydrates, proteins and lipids. Additional research is training now to determine the effect of potato irradiation on fatty and amino acids of PTM to more understand of the disturbance of its biology.

\section{ACKNOWLEDGMENTS}

We would like to thank Dr. Omar I. Saleh (National Center for Radiation Research and Technology) and Dr. Eman A. Mahmoud (Nuclear Researh Atomic Energy Authority) for their help and support.

\section{REFERENCES}

Avila, O. T.; Wood, H. A. and. Raguso, R. A. (2003). Effects of dietary variation on growth, composition, and maturation of Manduca sexta (Sphingidae: Lep.). :293-306.

Becker, D.P. and Somogyi, I.C. (1977). The action mechanism of the increase in sucrose content and phosphorylase activity after gamma-irradiation. Mitt. Gebitete Lebensm. Hyg. 68-409.

Bhat, R. and Sridhar, K. R. (2008). Nutritional quality evaluation of electron beamirradiated lotus (Nelumbo nucifera) seeds.: 174-184.

Bradford, M.M. (1976). A rapid and sensitive method for the quotation of microgram quantities of protein utilizing the principle of protein-dye binding. Anal. Biochem. 72: 248-254.

Chapman, R.F. (1998). The Insects: Structure and Function, 4th Ed.; Cambridge University Press: Cambridge, United Kingdom.

Dadd, R. (1985). Nutrition: organisms. In Comprehensive Insect Physiology, Biochemistry and Pharmacology G. A., Gilbert, L. I., Eds.; Pergamon Press: Oxford, United Kingdom,; 4: 313-390.

Diehl, J. F., (1995). Safety of Irradiated Foods, Second Edition, Marcel Dekker, Inc., New York,

Elton, G.A.H.(1978). European diets in relation to standards of need, in diet of men: Needs and wants (ed. J. Yudkin), Applied Science Puplishers, London, pp. 25-40. 
Elvin, W.; Tilton, J. H. B. and Cogburn, R. R. (1974). Insect control in wheat flour with gamma irradiation.: 301-305.

Engelmann, F. (1969). Female specie protein: biosynthesis controlled by corpus allatum in Leucophaea maderae. Sci., 165: 407- 409.

Fagan, W.F.; Siemann, E.; Mitter, C.; Denno, R.F; Huberty, A. F.; Woods , H. A. and Elser, J. J. (2002). Nitrogen in insects: implications for trophic complexity and species diversification. Amer. Natur. 160: 784-802.

Farkas, J. (2006). Irradiation for better foods.: 148-152.

Filep, G. and Koposztassy. E. (1971). Effect of temperature and gamma - irradiation on change in carbohydrate composition of some potato varieties during storage, Noventermeles. 20-289.

Godwin, H. O. (1977). Effect of gamma irradiation on the protein, amino acids and carbohydrate contents of soya-gari diet. 769-773.

Gomez, K.A and Gomez, A.A. (1984). Statistical procedures for agricultural research, 2nd edition. John Wiley and Sons, New York. 680 p.

Guy, J. H. (1999). Ionizing radiation quarantine treatments against tephritid fruit flies. : 93-106.

Haiba, I. M. (1994). Disinfestation of different varieties of potato naturally or artificially infested by the potato tuber moth, Ph. Operculella Zeller in the storage. J. Arb Nucl. Sci. and Appl. 27(3): 31-43.

Haiba, I. M. (2000). Integration of ash and gamma-irradiation for controlling the potato tuber moth, Ph. Operculella Zeller in storage. Bull. Ent. Soc. Egypt, Econ. Ser., 27: 78-107.

Hayashi,T. and Aoki, S. (1985). Effect of irradiation on the carbohydrate metabolism responsible for sucrose accumulation in potatoes. J. Agric. Fd. Chem. 33- 41.

Henry, D. (1998). Detection of food treated with ionizing radiation. : 73-82.

Jaarma, M. (1958). Influence of ionizing radiation on potato tubers. Arkiv. Kemi., 13-97. [ Cited in "The potato crop" Edited by Paul M. Harris, 1992].

Joern, A.; and Behmer, S.T.(1997). Importance of dietary nitrogen and carbohydrate to survival, growth, and reproduction in adults of the grasshopper Agenotettix deorum. Oecologia. 112: 201-208.

Josephson, E. S.; Thomas, M. H., and Calhoun, W. K. (1979). Nutritional aspects of food irradiation: An overview. J. Food Proc. Preserv. 2: 299-313.

Kai Fu, Y.; Tsai, C. Shi Wu, W.; Chang, M.; Chang.; Y and Shu, S. (1977). Food irradiation studies at the Institute of Nuclear Energy Research, Taiwan, Rep. of China.: 539-554

Kashani, G.G. and Valado, L.R. G. (1984). Effect of gamma irradiation on the lipid, carbohydrate and protein of Iranian pistachio kernels. J. Food Technol., 19(5):631-638.

Khan, I. (1990). Food irradiation development in Pakistan. International Journal of Radiation Applications and Instrumentation. Part : 245-247

Knight, J.A.; Anderson, S. and Rawle, J.M. (1972). Chemical basis of the sulfophospho-vanilin reaction for estimating total serum lipid. Clin. Chem. 18:199-202.

Kovács, E. I. ; Kiss, A. ; Boros, N. Y.; Horváth, J.; Tóth, P. G. and Szalma, Á. (1986). Disinfestations of different cereal products by irradiation 545-548.

Machaia, J. P.; Pedenkar, M. D. and Thomas, P. (1999). Reduction in flatulence factors in mung beans (Vigna radiate) using low dose gamma-irradiation. J. the Sci. Food and Agricul., 79(5):648-652. 
Machaia, J.P. and Pedenkar, M.D (2002). Carbohydrate composition of low dose radiation-processed legumes and reduction in flatulence factors. Food Chem., 79(3): 293-301.

Mondy, N.I. and Mueller, T.O. (1977). Potato discoloration in relation to anatomy and lipid composition. J. Food Sci. 14:42.

Rananavare, H. D; Harwalkar, M. R. and Rahalkar, G.W.(1991). Influence of modifying factors on induction of sterility and mating ability of potato tuberworm, Phthorimaea operculella (Zeller). J. Nucl. Agricul. and Biol., 20(3): 199-205.

Reese, J. C. and Field, M. D. (1986). Defense against insect attack in susceptible plants: black cutworm (Lepidoptera-Noctuidae) growth on corn seedlings and artificial diet. Ann. the Entomol. Soc. Amer., 79: 372-376.

Saour, G; Makee, H. and Al-Oudat, M. (1999). Susceptibility of potato plants grown from tubers irradiated with stimulation doses of gamma irradiation to potato tuber moth, Phthorimaea operculella Zeller (Lep., Gelechiidae). J Appl. Entomol., 123(3): 159-164.

Singh, N.B. and Sinha, R.N. (1977). Carbohydrate, lipidis and protein in the developmental stage of Sitophillus oryzea and Sitophillus grannarius. Ann. Ent. Sos. Amm.107-111.

Smith, J. W.; Behmer, S. T.; Lee, K P.; Raubenheimer, D. and Simpson, S. J. (2006). Evolving resistance to obesity in an insect. Proceeding of Nat. Acad. Sci., USA. 103 (38):14045-14049.

Stephanie, S. B. and Fischer, K. (2005). Effects of adult-derived carbohydrate, amino acids and micronutrients on female reproduction in a fruit-feeding butterfly.: 545-554.

Telang, A. and Wells, M. A. (2004). The effect of larval and adult nutrition on successful autogenous egg production by a mosquito. J. insect physiol.,: 677685.

Telang, A. ; Buck, N. A. and Wheeler, D. E. (2002). Response of storage protein levels to variation in dietary protein levels. J. Insect physiol., 48 (11): 1021-1029.

Telang, A.; Booton, V.; Chapman, R. F. and Wheeler, D. E. (2001). How female caterpillars accumulate their nutrient reserves.: 1055-1064.

Thorne, S. (1991). Food Irradiation. New York, NY: Elsevier Science Publishers;

Urbain, W. M., (1977). Radiation Chemistry of Proteins. pp. 63-130, in Radiation Chemistry of Major Food Components, P. S. Elias and A. J. Cohen, eds., Elsevier, Amsterdam.

Ussuf, K. K. and Nair, P. N. (1972). Metabolic changes induced by sprout inhibiting dose of gamma-irrdiation in potatos, J. Agric. Fd Chem. 20-282

Vigneron, J. P. (1978). Substances antiappetantes d'origine naturelle. Ann Zool. Ecol. Anim. 10: 633-694.

Villavicencio, A. H.; Araújo, M.M.; Fanaro, G.B.; Rela, P.R. ; Rela, J. M. and Mancini, F. J. (2007). Sensorial analysis evaluation in cereal bars preserved by ionizing radiation processing.: $1875-1877$.

Woodring, J. P.; Clifford, C. W and Beckman, B. R. (1979). Food utilization and metabolic efficiency in larval and adult house crickets.: 903-912. 


\section{ARABIC SUMMERY}

تأثير بعض مركبات الكيمياء الحيوية في البطاطس المشععة على فراشة درئنات البطاطس

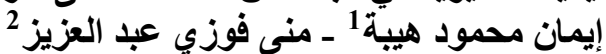

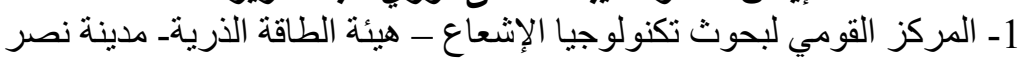

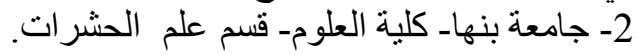

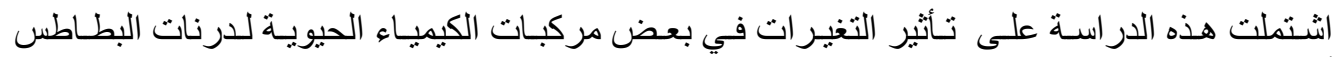

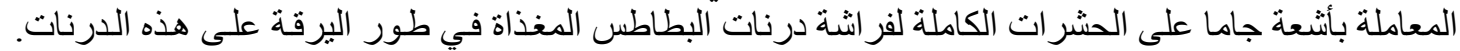
وقد تم استخدام الجر عـات الإثـعاعية 50، 70، 70، 100،

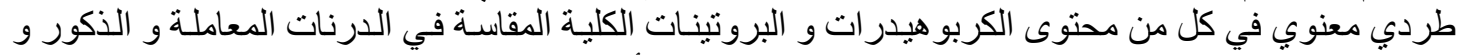

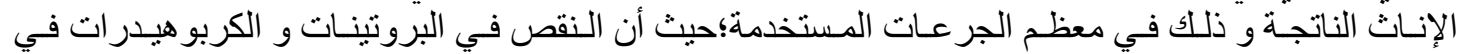

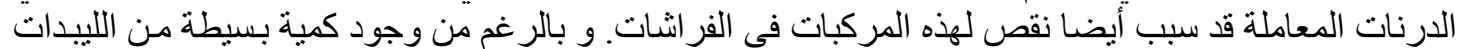

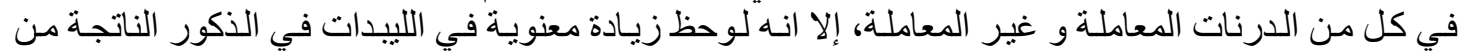

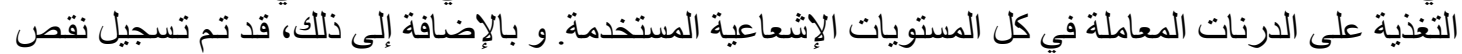

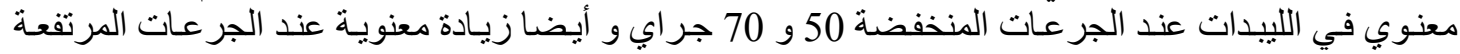

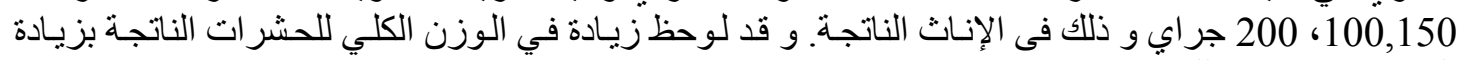
الجر عة الإشعاعية للبطاطس. 